Petr Havlan, Jan Janeček

\title{
TRANSFORMATION OF ALLOWANCE ORGANIZATIONS TO STANDARD PUBLIC SECTOR NON-PROFIT ORGANIZATIONS
}

\section{Introduction}

Transformation of allowance organizations to standard public sector nonprofit organizations (in fact, their transformation to independent public institutions) presents one of the basic problems of the Czech public finance at the beginning of the $21^{\text {st }}$ century. The core of the matter lies in particular in the absence of any more or less self-contained concept of the transformation. Solving this complex matter, with the necessary cooperation of representatives of theory and praxis - economists and lawyers - has still not been achieved. It would be very hard to find any corresponding concepts, specific rules and recommendations for future legislation or implementation of specific steps of transformation due to lack of such cooperation .

At the beginning the article deals with the issue of nature of allowance organizations and presents reasons why they are outmoded as forms of "non-profit subjects". As an aside a short discussion of the concept of "public institution" follows, supplemented by introduction of "non-profit subjects" as the subjects of property rights. Further, the first attempts of legal regulation of new non-profit subjects forms in Czech are appraised. At the end of the article the points defining the process of transformation pro futuro are stressed.

\section{The Nature of Allowance Organizations}

In the Czech Republic, the allowance organizations represent "traditional" and still the most common non-profit subjects. The allowance organizations occur in one of two possible forms - as allowance organizations of state or allowance organizations of local government. The Czech legislation treats a state allowance organization as 
a "temporary" one. These organizations act in all legal relations in their own names and on their own responsibility, at the same time they do not have (unlike in the past) their own title deeds or other property rights and all "their" property (tangible or intangible) is considered state property. Moreover, the state allowance organizations are not entitled any longer to the specific "right to dispose of property" any longer (in Czech "právo hospodaření"). They are just entitled to manage a defined set of state property. The current, weakened position of state allowance organizations as legal entities might be defined in brief like this: they do not have (unlike in the past) the capacity to own property; according to current legislation they are not entitled to any other right concerning the property they are managing, actually they do not own any property. The fact that state allowance organizations are legally bound to meet the obligations resulting from their activities and those pertaining to the property they manage, appears to be quite interesting in this context.

The regulations currently in force allow local governmental units to establish allowance organizations which are "legal entities that in most of their activities operate as non-profit". The temporary nature of this form of legal entity is not indicated, unlike in the case of state allowance organizations. The allowance organizations of local governmental units are legal entities sui generis and have almost the same characteristics as state allowance organizations. It means, they are incapable of ownership ${ }^{1}$, they do not own any tangible property, they are incapable to do so, they are just entitled to a specific "right of management" (in Czech "správa") relating to a defined set of local governmental property. Their main characteristics, concerning the rights of property, constitute in fact so called "other entities" (in the sense of section 18(2)(d) of Czech Civil Code) which have their own capacity in relation to property. The capacity allows them just to manage their founder's property and manage the property owned by their founder (the local governmental unit in question). "The tool" which allows the allowance organization to manage and administer the property, the so called "right of management", is in fact a special proprietary provision of public law (unlike the management of someone else's property based on private law). This special provision of public law is unfortunately poorly and insufficiently regulated, which results in some confusion. We can add that the allowance organizations belonging to local governmental units are usually established to carry out duties which fall under the competence of their establishers (which, as already mentioned above, are usually non-profitable and their scope, structure and complexity demand legal subjectivity) ${ }^{2}$.

1 We regret to say that the upcoming amendment to Act no. 250/2000 Coll. of $7^{\text {th }}$ July 2000 on Budgets of LocalGovernmental Units (in Czech "zákon č. 250/200 Sb., o rozpočtových pravidlech územních rozpočtư"), which was supposed to express (by its new section $27(2)$ ) this fact explicitly by words "an allowance organization does not have its own property; it manages property of its establisher and acquires property for its establisher", was withdrawn.

2 The detailed information on the definition, nature, establishment, alteration and cancellation, as well as on legal activities of state allowance organizations and allowance organizations of local governmental unit might be found 


\section{The Concept of "Public Institution" (in Czech "veřejný ústav")}

First of all, it is necessary to point out that the concept of "public institution"/ "independent public institution" in the Czech Republic is defined just by doctrine and not by law. It means that it serves "only" as a kind of common denominator for several legally defined legal entities, typified by their non-profitable nature

It is necessary to mention, in connection with the definition of symptomatic attributes of public institutions presented later, that it concerns just the basic attributes which might be more or less acceptable according to the contemporary Czech doctrine (another point is the individual assessment of importance of any single "symptomatic feature"). A public institution might be defined as a unit which is:

- a legal entity established by law or by an administrative act based on the law, which at the same time defines the range and the character of its legal capacity,

- established to fulfill a public purpose,

- without a member base, so the question of its potential local governmental character is "overshadowed", which makes it different from public corporations - customary establishers of public institutions (state, local governmental unit),

- organized in a hierarchical manner,

- focused on long-lasting fulfillment of public services aimed at an unspecified group of entities (possible users who are legally entitled to such service) who are not obliged to cooperate actively, yet their cooperation is not precluded,

- in principle, with a focus on non-profit activities, which makes it different from a "public enterprise" (in Czech "veřejný podnik"). 3,4

in P. Havlan, Majetek státu v platné právní úpravě, Prague, 2006, pp. 55-69, and in P. Havlan et all, Majetek obcí a krajů v platné právní úpravě, Prague, 2008, pp. 35-44 and 49-51.

3 There is a widespread agreement in theory, that it is possible to establish so called "dependent public institutions" (see for example D. Hendrych, in D. Hendrych et all, Správní právo. Obecná část, Prague, 2006, p. 108 and literature cited therein), which represent mere organizational units (facilities) without a legal personality. The organizational units mentioned might be, according to the Czech legal regulation in force, established as "state organizational units" (in Czech "organizační složka státu") or as "organizational unit of local governmental unit" (in Czech "organizační složka územního samosprávného celku”). For more information on their definition, nature, establishing, alteration and closure, as well as on their legal activities see P. Havlan, Majetek státu v platné právní úpravě, Prague, 2006, pp. 34-43, and in P. Havlan et all, Majetek obcí a krajů v platné právní úpravě, Prague, 2008, pp. 27-35. However, the mentioned "dependent public institutions" are not the subject matter of this paper.

4 The fact that there are doctrinal definitions of a "public institution", as well as of, for example, "public enterprise" does not automatically mean that they will be realised in law. In this context, it is possible to mention the recent situation in France, where a cursory glance at two basic types of public institutions shows that one of them, 


\section{Non-profit Subjects as Proprietary Subjects}

Legal subjects of so called private law as well as legal subjects of so called public law might be non-profit subjects ("organizations"). Foundations (in Czech "nadace a nadační fondy") according to Act no. 227/1997 Coll. of $3^{\text {rd }}$ Septemper 1997 (in Czech "zákon č. 227/1997 Sb., o nadacích a nadačních fondech") present a typical example of private law non-profit subjects accumulating property for the given generally beneficial aims. These subjects might be established both by natural or legal persons. Foundations come into being on the day when they are entered into the Register of Foundations (in Czech "nadační rejstř́ik"). A foundation is managed by the council entitled to dispose of the profit from foundational property to fulfill the purpose for which the foundation was established. The council also manages the other property belonging to the foundation. All the property of the foundation is employed towards its particular beneficial aims. The core of the matter is, that it is the foundational property and other property of a foundation itself what constitutes the non-profit subject of this type. "A company for the provision of beneficial services" (in Czech "obecně prospěšná společnost") is as a second example of a non for profit organization subject to private law regulated by Act no. 248/1995 Coll. of $28^{\text {th }}$ September (in Czech "zákon č. 248/1995 Sb., o obecně prospěšných společnostech"). This non-profit subject provides generally beneficial services based on predefined conditions, to everyone on equal basis. It might be established, as the act says, by a natural person, the Czech Republic or another legal person. Likewise, this organization comes into being on the day when it is entered into the appropriate register. The statutory body of this organization is its council, the other bodies are director and supervisory board (in Czech "dozorčí rada"). Corporation assets comprise initial deposits of founders, received donations and inheritance, corporation's funds and subsidies.

Finally, let us turn our attention to the legal subjects mentioned above, specifically to legal subjects of so called public law - non-profit ("organizations"), subjects of public-law especially to the most typical of those - "public institutions". In particular we would like to appraise the first attempts to incorporate other types of independent public institutions into the Czech legal system, especially those that would be different from those incapable to own property, thus "handicapped" allowance organizations.

"administrative public institution" (in French "éstablissement public administrative"), is in fact a body subject to public law, on the other hand the other, "public industrial and commercial institution" (in French "éstablissment public industriel et commercial"), is a body subject to private law. These two institutions have several characteristics in common: they are legal entities owning property and they have their own budgets. 


\section{On New Forms of Non-Profit Subject of the Czech Law}

"Educational legal entity" (in Czech "školská právnická osoba”) represents a transitional type of legal entity which entered the Czech legal system on $1^{\text {st }}$ January 2005, when the new Schools Act of $24^{\text {th }}$ September 2004 (in Czech “zákon č. 561/2004 Sb., školský zákon") came into force. This sui generis legal subject proves that the concept of a "legal subject" is more a "product" of legislation - a concept created and afterwards recreated and changed by legislation - than a construct of theoretical exploration ("a prior concept"). Taking this into account, it is not surprising that from the theoretical point of view the question is whether "educational legal entity" meets the "parameters" of a "public institution". On the other hand, it is necessary to appreciate that this entity shows at least few "embryonic" features of a modern public legal subject. Section 140 of the Schools Act is worth bearing in mind in this case. It states that "educational legal entity" for the purposes of its own activities uses its own property and the property borrowed from or hired by its establisher or another entity. Further, the principles of approbation and control mechanisms are laid down for the cases where state or local governmental units (or municipal unions) are the establishers of an "educational legal entity" [see section 129(2) and 136(3) of Act on Schools].

The start of the "journey" to modern types of "public institution" might be traced to Act no. 341/2005 Coll. of $28^{\text {th }}$ July 2005 (in Czech "zákon č. 341/2005 Sb., o veřejných výzkumných institucích"), coinciding with the emergence of a "public research institution". "Public research institution" emerged as a part of Czech legal system (on the basis of transitory provision of section 31 of Act no. 341/2005 Coll. mentioned above) on $1^{\text {st }}$ January 2007, which meant that the transformation of more than 70 state allowance organizations operating in the field of scientific research and of two established by local government regions, which is of high significance ${ }^{5}$, was completed. Especially the capacity of "public research institution" to own property is, from our point of view, quite a significant feature of this legal entity. Thus, this kind of public institution is not just competent to manage the defined set of the state tangible property, as state allowance organizations are, or just entitled to the specific "right of management" relating to the defined set of local government property, as allowance organizations of local governmental units are, but it directly owns tangible assets. In other words, a "public research institution" is the first step towards the

For the sake of precision, it should be noted that the transformation of the above allowance organizations concerned "Institution for the Conservation of Archaeological and Historical Sites in Brno" (in Czech "Ústav archeologické památkové péče Brno"), on the basis of decision no. 397/05/Z6 made on $8^{\text {th }}$ November 2005 by the Regional Assembly of South Moravia (in Czech "Zastupitelstvo Jihomoravského kraje") and "Institution for the Conservation of Archaeological and Historical Sites in North-west Bohemia, allowance organization" (in Czech "Ústav archeologické památkové péče severozápadních Čech, příspěvková organizace”) on the basis of decision no. 20/8Z/2005 made on $26^{\text {th }}$ October 2005 by Regional Assembly of Ústí region (in Czech "Zastupitelstvo Ústeckého kraje"). 
concept of new peculiar public legal entity fulfilling the functions of recent allowance organizations and which is, at the same time, fully capable of owning property. In theoretical or practical argument with those, who in fact attempt a "privatisation" of public forms of legal entities, by replacing them with private law forms (typically as trading companies), it is insufficient to say that "public legal entities are just and useful". Such an argument would be rejected (often just on ideological grounds). In such a polemic, it is necessary to bring theoretical concepts of new progressive public legal entities (for example of "public institution", as discussed here) and, what is more, it is necessary to turn theory into practice, in other words to enact them. From this point of view the legislative steps taken from the concept of allowance organizations to "public research institutions" appear small, but positive.

To define "public research institution" a little more precisely we should add the following: research and provision of infrastructure for research represent the scope of "public resource institution" activities as defined by section 2(1)(a) and section 2(2)(f) of Act no. 130/2002 Coll. of 14 ${ }^{\text {th }}$ March 2002 on Support of Research and Development (in Czech "zákon č. 130/2002 Sb., o podpoře výzkumu a vývoje"). Their main activities aim at research supported from public sources in compliance with Art. 87 and 89 of the EC Treaty. "Public research institution" might be established by the Czech Republic or by a territorial local governmental unit. Legal obligations between "public research institutions" and between a "public research institution" on one side and a state or a local governmental unit or a public university on the other, are governed by Commercial Code, if the obligation concerns main, additional or another activity of the "public research institution". Legal obligations between a "public research institution" and entrepreneurs which concern main, additional or another activity of the "public research institution" and, mutually, business activity of entrepreneurs are governed by the Commercial Code as well. The establishment of a "public research institution" bears upon the release of the deed of establishment by the establisher. This institution comes into being on the day when it is entered into the "Public Research Institution Register", as the law prescribes.

Discussing the competence of the "public research institution's" establisher, we might say that it is defined in a way which is "up-to-date". The founder cannot directly interfere in activities of a "public research institution", on the other hand the establisher might, via a "supervisory council", supervise the property which has been invested. Also the founder might, via a "supervisory council", supervise whether the purpose for which the institution was established is pursued. The establisher's capability to restrict disposal of the institution's property (besides performance of the establisher's functions) expresses its direct influence upon the "public research institution". Under the law, the establisher's approval of legally defined set of acts in law is required, but first these acts in law might be approved in writing by the "supervisory council" of the institution. 
"Public research institution" has the following bodies: the "director", the "council of the institution" and the already mentioned "supervisory council". Within the scope of unified management, steps are taken to balance these three factors self-governing management, influence of experts and justified interests of the establisher. The director is entitled to act independently in operational matters, but several tasks defined by law (property management, budget, internal norms) should be solved in cooperation with the "council of the institution". The "council of the institution" is designed as a self-governing (research) management and at the same time as an executive council. In that way the "council of the institution" has a crucial influence on the institution's performance and its long-term development strategy. The "council of the institution" does not interfere in operational matters of day to day management. This is the "director's" duty. The "supervisory council" then forms a body which was designed to supervise any property "transferred" to the institution, as well as to supervise the management of property and finance obtained for attaining the purpose that the institution was established for.

As far as the law is concerned, it is crucial for property management of "public research institution" to use assets to accomplish its main tasks (research or infrastructure). The property might be used for other or extra activities only in the cases specified by law. "Additional activity" ("další činnost" in Czech) is defined as an activity executed on request of a competent "state organizational unit" or a local government unit, on condition that such an activity is in public interest and supported by public resources in accordance with special regulations. "Other activity" ("jiná činnost" in Czech) is defined as an economic activity executed to gain profit. There is an important rule saying that costs of "additional activity" or "other activity" of a "public research institution" cannot be covered from public sources determined to support research and these activities must be executed in compliance with conditions set by law (see section 21(3) of cited legal act). If by the end of accounting period the trading result from "other activity" or "additional activity" is a loss, then the institution is obligated to cancel such activity immediately".

Nowadays it is clear that the positive development outlined above, presented by Act no. 341/2005 Coll., in respect to the category of "public research institution", will not be straightforward, if at all. For example, the way a "public non-profit institutional health facility" (in Czech "veřejné neziskové ústavní zdravotnické zarrízení") got constituted proves it. At that point, the sphere of health services seemed to be hopeful to continue the trend which started with the adoption of the

6 More information on institutions in question can be found in P. Havlan, Veřejné výzkumné instituce, Právní zpravodaj, 12, 2005, p. 10. For more information on finance management of "public research institutions" and on their taxation see H. Marková, Veřejné výzkumné instituce - pojem, právní postavení, hospodaření a zdaňování v České republice, In Sborník "Aktuální otázky vybraných institutů práva neziskového sektoru" (Z. Hudcová, ed.), Olomouc, 2007, pp. 1005-112. 
Act on "public research institution". The legislative design of the Act on health facilities was rather promising, presenting the concept of a so called "public health organization" (in Czech "veřejná zdravotnická organizace"). In particular, the fact that "public health organization" was designed as a "complete" legal entity owning its own property and managing it, showed potential. Its designed structure, composition of its bodies and several aspects of its management and supervision invoked the expectation of constituting a modern "public institution". The end result, however, was different. Act no. 245/2006 Coll. of $21^{\text {st }}$ April 2006 on "public nonprofit institutional health facility" and on amendment to some acts (in Czech "zákon č. 245/2006 Sb., o veřejných neziskových zdravotnických ústavních zařízeních a o změně některých zákonư") was passed on the basis of an MP's bill. This act, more than anything else, discredits, due to low quality of its legislative works,, the principles on which the above mentioned legislative design of Act on health facilities was based. Act no. 245/2006 Coll., in its section 40, constituted an unallowable mechanism of transforming the provision of health services (by business companies), which was after all annulled by the Constitutional Court of the Czech Republic ${ }^{7}$. The codified existence of two various forms of property treatment is another thing to be criticical of. In fact, property vested by the establisher in "public non-profit institutional health facility" might remain (on the basis of a deed of foundation) the property of the establisher, or it might become the property of the "public non-profit institutional health facility". Property acquired from the activity of the "public nonprofit institutional health facility" shall always be owned by this subject [see section 13(2)(a) and (b) of above cited Act] $]^{8}$.

The attempts to transform faculty hospitals as they are defined by section 93 of Act no. 111/1998 Coll. of 22 $2^{\text {nd }}$ April 1998 on Universities (in Czech "zákon č. 11/1998 Sb., o vysokých školách"), (faculty hospitals provide clinical and practical teaching in the sphere of medicine, pharmacy and other health disciplines, as well as scientific research and development activities; faculty hospitals are established by the Ministry of Health as state allowance organizations) into "university hospitals", represents an "unhealthy" development in the field of health services, as well as in the field of higher education. These "university hospitals" are designed to be jointstock companies, instead of "complete" (full-fledged, capable to own) independent "public institutions" (even thought under the circumstances it suggests itself).

See the decision of The Constitutional Court of the Czech Republic no. PL ÚS 5106 (published under no. $483 / 2006$ Coll.) of $27^{\text {th }}$ September 2006. As far as the authors know, till today no "public non-profit institutional health facility" was established. The "Register of public non-profit institutional health facility" as defined in section 27(7) of Act no. 245/2006 Coll. was not established till today either, which is very significant.

8 On difficulties of such a solution see P. Havlan et all, Majetek obcí a krajů v platné právní úpravě, Prague, 2008, pp. 44 and 45 . 


\section{Transformation - "Pro Futuro"}

A certain shift in concepts of non-profit subjects ("independent public institutions"), especially expressed by the codification of "public research institution", does not mean that the above mentioned concept of "public legal entities" is becoming reality in the Czech Republic. We are still lacking a universal (not defined just for specific spheres of public administration") legal form of "public institutions", which would comprise "complete" (full-fledged) subjects [capable of] of ownership, not just "executors" of their establisher's property rights, regardless of whether they still remain partially dependent on their establishers concerning proprietary matters. None but a legal subject based on this proprietary basis might really effectively operate and its effective financing, managing and supervising might be assured. None but these non-profit subjects are able to fulfill their social function of stabilisation and development.

9 From that point of view the recent practice of establishing ministerial commitees for transformation of allowance organizations operating just in a specified sphere of public administration seems to be an unfortunate step. 


\section{Streszczenie}

Przedmiotem rozważań w niniejszym opracowaniu jest charakter organizacji przyznających pomoc socjalną i ich forma działalności, którą należy uznać za przestarzałą wobec współcześnie funkcjonujących organizacji non-profit. Rozważania dotyczą między innymi definicji ,publicznej instytucji” i przedmiotu jej działalności, podnoszone są krytyczne uwagi wobec ostatnio wprowadzonych regulacji prawnych w tym zakresie, podkreślając jednocześnie potrzebę zmian w przyszłości. 